\title{
Editorial
}

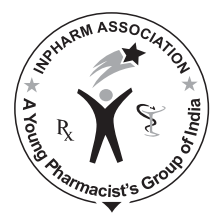

JIP

\section{My Vision: J Young Pharm}

Dear Professional Colleagues, Researchers, Fellow Students and Readers,

First, I on behalf of the Editorial Board would like to thank all authors, reviewers, readers, subscribers, editorial staff and publisher for their constant support on growth of the Journal of Young Pharmacists (J Young Pharm). This issue marks the official handing over of the journal editorship from Dr. Mueen Ahmed KK to myself. ${ }^{[1]}$ His leadership has been invaluable in this journal's growth and building the quality that I now inherit. ${ }^{[2]}$ I am grateful for this to Dr. Ahmed and am pleased to announce that he will continue to work with us as a publishing editor and executive editorial member. I would also like to acknowledge Dr. Ahmed and his team efforts over the past four years.

J Young Pharm is an official journal published by InPharm Association (Bangalore) and published its first issue on June 04, 2009. So far, J Young Pharm has published four volumes comprising 13 issues under the editorship of Dr. Mueen Ahmed KK, Asst. Professor, Department of Pharmacognosy, Al-Ameen College of Pharmacy, Bangalore, India. Under his leadership, the journal has achieved many milestones in terms of indexing such as Pubmed, Pubmed-central, Index Copernicus, SCOPUS and other indexing databases. Within a short span of time, the journal has received a projected impact factor of 0.342 (as calculated from the tool available at Medknow website); ${ }^{[1,3]}$ however, we are yet to be indexed in Science Citation Index or related databases to obtain the official impact factor.

The journal has been publishing a wide variety of articles in biomedical/pharmaceutical research, and the journal

\begin{tabular}{|l|l|}
\hline \multicolumn{2}{|c|}{ Access this article online } \\
\hline Quick Response Code: & \\
\hline & Website: \\
\hline & www.jyoungpharm.in \\
& \\
\hline
\end{tabular}

Journal of Young Pharmacists Vol 4 / No 3 platform offers complete online facility to web-based uploading of manuscript, manuscript tracking system via journalonweb.com ${ }^{[4,5]}$ and free online access of published papers (HTML format). It is time to move ahead. At present, the journal has a new editorial team, consisting of energetic active individuals who are in biomedical/ pharmacy research with great experience in their chosen field of specifications.

My editorial experience and knowledge of publishing articles emanates from Journal of Pharmacology and Pharmacotherapeutics, another official journal of the InPharm Association (Bangalore), starting out as its editorial assistant in 2010 and becoming its assistant editor in 2012. My vision is to manage journal operations transparently with the help of editorial board members and reviewers. The progress and performance of $J$ Young Pharm will be discussed constantly with editorial board members and publishing editor. In its new dimension, the present editorial board is planning to introduce graphical abstract for original articles and is planning to make compulsory submission of CONSORT statement and CONSORT flowchart for clinical studies. The present editorial board aims to ensure the quality of the research report, and we expect authors to follow the World Association's Declaration of Helsinki and request all the authors to submit a copy of ethical clearance letter along with their manuscript submission (if applicable). From this point onward, the journal will encourage consideration of multidisciplinary nature of manuscript from the biomedical research community as well.

On behalf of the journal, I would like to invite researchers worldwide to publish their research work, review articles and research communications in J Young Pharm and make it a valuable biomedical/pharmacy journal of Indian origin. I welcome any constructive suggestions from the readers to improve the journal and quality of papers. 
Parasuraman S $\quad$ 2. Mueen AK. The launch of J Young Pharm. J Young Pharm 2009;1:1.

Editor-in-Chief, J Young Pharm.,

3. Mueen AK. White paper on J Young Pharm Statistics JYP: Where do we stand!! J Young Pharm 2010;2:1.

Department of Pharmacology, Jawaharlal Institute of

4. Mueen AK. J Young Pharm. 2011: What are we aiming at? J Young Pharm 2011;3:1.

Postgraduate Medical Education \& Research (JIPMER),

Pondicherry, India

E-mail: parasuphd@gmail.com

5. Mueen AK. Why do we need quality articles, what are we going to do with? J Young Pharm 2011;3:81

\section{REFERENCES}

1. Mueen AK. Outgoing editor. J Young Pharm 2012;2:1.

How to cite this article: Parasuraman S. My Vision: J Young Pharm. J Young Pharmacists 2012;4:127-8. 